\title{
Ilmaston lämpeneminen tuo uusia kasvilajeja ja -lajikkeita viljelyyn, mutta myös uusia haasteita kasvinsuojelulle
}

\author{
Kaija Hakala, Asko Hannukkala, Erja Huusela-Veistola ja Pirjo Peltonen-Sainio \\ MTT, Kasvintuotannon tutkimus, 31600 Jokioinen, e-mail: etunimi.sukunimi@mtt.fi
}

\section{Tiivistelmä}

Ilmasto on muutaman viime vuosikymmenen kuluessa selvästi lämmennyt maailmalla ja myös Suomessa. Kasvukausi on pidentynyt, lämpösumma on noussut ja talvet ovat leudontuneet. Pidempi kasvukausi ja suurempi tehoisa lämpösumma luovat paremmat edellytykset kasvintuotannolle. Kasvintuotantoa edistävät muutokset yhdistettyinä leudompiin talviin ja lisääntyvään syksyn ja talven sademäärään luovat kuitenkin paremmat edellytykset myös peltoviljelyn haittana oleville rikkakasveille, taudeille ja tuholaisille.

Ilmastonmuutoksen vaikutus perunaruton ja perunan tyvimädän yleistymiseen on jo nähtävissä. Myös viljoille on tullut uusia lehtilaikkutauteja ja jo olemassa olevat taudit ovat alkaneet aiheuttaa laajempia tuhoja. Kun kasvukausi pitenee ja viljelyyn otetaan yhä pidemmän kasvuajan lajikkeita, ne altistuvat taudeille pitempään. Esimerkiksi perunaruton osalta ehkä lähestytään tulevaisuudessa Hollannin tilannetta, jossa pahoina vuosina tarvitaan tällä hetkellä jo yli 20 ruttoruiskutusta, kun Suomessa ruiskutetaan tyypillisesti 5-8 kertaa. Myös uusia tauteja on odotettavissa. Jo nyt ovat perunan Dickeyatyvimätä, uudet Y-viruksen rodut ja jopa uusi perunaruttorotu valtaamassa alaa vanhoilta taudeilta. Muita uhkia ovat mm. koloradonkuoriaisen ja ankeroisten leviäminen siementuotantoalueelle sekä uudet Y-virusta levittävät kirvalajit.

Uusia syysmuotoisia viljelykasveja voidaan ottaa laajemmin viljelyyn, kun talvet leudontuvat. Esimerkiksi syysvehnää tullaan jo lähivuosikymmeninä viljelemään koko Etelä-Suomen alueella ja syysmuotoinen ohrakin otetaan viljelyyn tämän vuosisadan lopulla. Syysmuotoiset kasvit voivat sopeuttaa kasvintuotantoa muuttuviin oloihin kohentuvan vesitalouden kautta, kun kasvit voivat käyttää talven sateista jääneen maan kosteuden kuivana alkukasvukautena. Syysmuotoiset kasvit ovat myös yleensä satoisempia kuin keväällä kylvettävä, mutta niiden laajeneva viljely tuo myös uusia ongelmia. Tulemme saamaan esim. aivan uudenlaisen ohran härmäongelman, mikä lisää tautiruiskutusten tarvetta olennaisesti. Syksyjen lämpeneminen ja syysmuotoisten viljojen viljelyn laajeneminen lisäävät myös tuholaisten, kuten kahukärpänen ja hesseninsääski, aiheuttamia tuhoja. Myös kirvojen ja kaskaiden levittämien virustautien (BYDV, WDV) merkitys todennäköisesti kasvaa.

Myös aivan uudet viljelykasvilajit saattavat tuoda omat ongelmansa Suomen maatalouteen. Rehumaissia saatetaan viljellä Etelä-Suomessa merkittävissä määrin jo vuonna 2055 (30 v keskiarvo tämän vuosiluvun molemmin puolin) ja vuonna 2085 ( \pm 30 v.) jo Jyväskylän seuduille asti. Vaikka emme odota varsinaista jyvämaissia Suomeen vielä tämän vuosisadan puolella, maissi sinänsä voi tuoda uusia tauti- ja tuholaisongelmia. Jos vehnää ja maissia on samassa viljelykierrossa, punahomeet tulevat vaivaamaan kasvustoja entistä enemmän. Maissin tuholaisista maissikoisaa esiintyy Suomessa jo satunnaisesti, vaikkakaan ei maissin tuholaisena. Mallinnusten mukaan se voisi menestyä Suomessa, kun sen pääisäntäkasvin eli maissin viljely lisääntyy. Maissin muita viljoja myöhäisempi kylvöaika lisää kahukärpäsen vioitusriskiä ja alttiutta kirvojen levittämille virustaudeille.

Asiasanat: ilmastonmuutos, maissi, palkokasvit, peruna, talvehtiminen, taudit, tuholaiset, viljat, virukset 


\section{Ilmasto lämpenee ja kasvintuotanto hyötyy}

Ilmasto on muutaman viime vuosikymmenen kuluessa selvästi lämmennyt maailmalla ja myös Suomessa (IPCC 2007). Kasvukausi on pidentynyt, lämpösumma on noussut ja talvet ovat leudontuneet (Klein Tank et al. 2002). Tulevaisuudessa maapallon lämpeneminen jatkuu ainakin 2 asteen verran seuraavan vuosisadan kuluessa, mutta jopa 5-6 astetta, jos päästöjä ei saada kuriin. Odotettavissa on myös sademäärien muutoksia ja ilmaston vaihtelevuuden lisääntymistä (IPCC 2007). Pohjoisilla alueilla, kuten Suomessa, ilmasto lämpenee enemmän kuin matalilla leveysasteilla, mutta myös sademäärä kasvaa, toisin kuin esim. Afrikassa ja Välimeren maiden alueella, joille on ennustettu lisääntyvää kuivuutta. Sademäärä kasvaa Suomessa vain vähän kasvukaudella (kesä-, heinä- ja elokuu), ja varsinkin kevät jää edelleen hyvin kuivaksi, etenkin kun ottaa huomioon samalla kohoavan lämpötilan ja sitä seuraavan lisääntyvän haihdunnan (Jylhä et al. 2004). Syys- ja talvisateet sen sijaan runsastuvat reippaammin (Jylhä et al. 2004). Tämä ei kuitenkaan enää hyödytä kasvien sadontuottoa, vaan vain vaikeuttaa korjuita ja syysviljojen kylvöjä sekä aiheuttaa laadun huononemista. Kaiken kaikkiaan pidempi kasvukausi ja suurempi tehoisa lämpösumma luovat paremmat edellytykset Suomen kasvintuotannolle. Voidaan ottaa käyttöön nykyistä satoisampia viljelykasvilajeja ja lajikkeita sekä uusia syysmuotoisia kasveja, samalla kun nykyisiä viljelykasveja voidaan viljellä laajemmalla alueella Suomessa (Peltonen-Sainio et al. 2009). Kasvintuotantoa edistävät muutokset yhdistettyinä leudompiin talviin ja lisääntyvään syksyn ja talven sademäärään luovat kuitenkin paremmat edellytykset myös peltoviljelyn haittana oleville rikkakasveille, taudeille ja tuholaisille (Carter et al. 1996).

\section{Lämpimämpi ja pidempi kasvukausi tuo uusia tauteja ja tuholaisia}

\section{Perunan uudet taudit ja tautirodut lisääntyvät kasvukauden lämmetessä ja pidetessä}

Kuluneiden vuosikymmenten aikana tapahtunut ilmaston lämpeneminen on jo nyt vaikuttanut perunaruton ja perunan tyvimädän yleistymiseen. Lämpenemisen jatkuminen tullee lisäämään tautialtistusta. Esim. perunaruton osalta lähestytään ehkä vähitellen Hollannin tilannetta, jossa pahoina vuosina tarvitaan jo nyt yli 20 ruttoruiskutusta, kun Suomessa ruiskutetaan tyypillisesti 5 - 8 kertaa kasvukaudessa (Hannukkala et al. 2007). Myös uusia tauteja on odotettavissa. Perunan Dickeyatyvimätä on jo nyt syrjäyttänyt vanhat Erwinia-taudit (Laurila et al. 2008), Y-viruksen ntn-rotu on korvannut vanhat n- ja o- rodut 2007-2008 (Hiltunen et al. 2008, Kirchner et al. 2009), ja 1990-2000 taitteessa tuli uusi perunaruttorotu, joka syrjäytti vanhan (Lehtinen et al. 2007). Muita uhkia ovat mm. koloradonkuoriaisen ja ankeroisten leviäminen siementuotantoalueelle (Lyytinen et al. 2007) ja uudet Y-virusta levittävät kirvalajit (Kirchner et al. 2009).

\section{Viljojen pitempi kasvuaika ja uudet viljelykasvilajit suosivat nykyisiä ja tuovat uusia tauteja ja tuholaisia}

Viljakasvit ovat jo nyt kärsineet laajenevia tuhoja meille entuudestaan tuttujen tautien takia. Myös uusia lehtilaikkutauteja on alkanut tulla Suomeen. Kun kasvukausi pitenee, viljelyyn otetaan yhä pidemmän kasvuajan ja paremman satotason lajikkeita (Peltonen-Sainio et al. 2009). Vaikka tällaisten lajien viljely on taloudellisesti kannattavaa suurten satojen takia, ne altistuvat taudeille pitempään pitkän kasvukauden ansiosta.

Uudet viljelykasvilajit saattavat tuoda omat ongelmansa Suomen maatalouteen. Esim. rehumaissia saatetaan viljellä Etelä-Suomessa merkittävissä määrin jo vuonna 2055 (30 v keskiarvo tämän vuosiluvun molemmin puolin) ja vuonna 2085 ( \pm 30 v.) jo Jyväskylän seuduille asti (PeltonenSainio et al. 2009). Vaikka emme odota varsinaista jyvämaissia Suomeen vielä tämän vuosisadan puolella, rehumaissikin voi tuoda uusia tauti- ja tuholaisongelmia. Jos vehnää ja maissia on samassa viljelykierrossa, punahomeet tulevat vaivaamaan kasvustoja entistä enemmän. Maissin tuholaisista maissikoisaa esiintyy Suomessa jo satunnaisesti, vaikkakaan ei maissin tuholaisena. Mallinnusten mukaan se voisi menestyä Suomessa, kun sen pääisäntäkasvin eli maissin viljely lisääntyy (Tiilikkala et al. 2010). Maissin muita viljoja myöhäisempi kylvöaika lisää kahukärpäsen vioitusriskiä ja alttiutta kirvojen levittämille virustaudeille. 


\section{Syysmuotoisten kasvien viljelyn mukanaan tuomia tauti-ja tuholaisongelmia}

Uusien syysmuotoisten viljelykasvien otto viljelyyn tuo uusia ongelmia. Esimerkiksi syysvehnää tullaan jo lähivuosikymmeninä viljelemään koko Etelä-Suomen alueella ja syysmuotoinen ohrakin otetaan viljelyyn tämän vuosisadan lopulla. Tällöin syysmuotoisten viljojen viljelyn ongelmat yleistyvät. Tulemme mm. saamaan aivan uudenlaisen ohran härmäongelman, mikä lisää tautiruiskutusten tarvetta olennaisesti. Syksyjen lämpeneminen ja syysmuotoisten viljojen viljelyn laajeneminen lisäävät kahukärpäsen ja hesseninsääsken aiheuttamia tuhoja (Huusela-Veistola et al. 2006). Myös kirvojen ja kaskaiden levittämien virustautien (BYDV, WDV) merkitys todennäköisesti kasvaa (Harrington 2007, Huusela-Veistola 2007, Huusela-Veistola \& Lemmetty 2005). Myös syysmuotoisten öljykasvien viljelyn lisääntyminen muuttaa kasvitauti- ja tuhoeläintilannetta (Tiilikkala et al. 2010).

\section{Kirjallisuus}

Carter, T.R., Saarikko, R.A. \& Niemi, K.J. 1996. Assessing the risks and uncertainties of regional crop potential under a changing climate in Finland. Agricultural and Food Science in Finland 5: 329-350.

Hannukkala, A., Kaukoranta, T., Lehtinen, A. \& Rahkonen, A. 2007. Late-blight epidemics on potato in Finland, 1933-2002; increased and earlier occurrence of epidemics associated with climate change and lack of rotation. Plant Pathology 56: 167-176.

Harrington, R. 2007. Viruses, vectors, host plants and environment: From complexity to control. In: NJF Seminar 402 : Virus vector management in a changing climate, preliminary report, Kristianstad, Sweden, 9-11 October 2007. p. 9-11.

Hiltunen, L., Kirchner, S., Tian, Y., Virtanen, E. \& Valkonen, J. 2008. Perunan Y-viruksen levintä ja rodut tarkastelussa. Tuottava peruna 2: 13.

Huusela-Veistola, E. 2007. Overview of vectors of cereal viruses in Finland. In: NJF Seminar 402 : Virus vector management in a changing climate, preliminary report, Kristianstad, Sweden, 9-11 October 2007. p. 4344.

Huusela-Veistola, E.\& Lemmetty, A. 2005. Viirukaskaan levittämää vehnän kääpiökasvuvirusta Suomessa. Kasvinsuojelulehti 38 (1): 8-10.

Huusela-Veistola, E., Jalli, H., Salonen, J., Pahkala, K. \& Laine, A. 2006. Sowing time affects the abundance of pests and weeds in winter rye. Agricultural and Food Science 15, 1: 43-60.

IPCC 2007. Summary for Policymakers. In: Climate Change 2007: The Physical Science Basis. Contribution of Working Group I to the Fourth Assessment Report of the Intergovernmental Panel on Climate Change. Solomon, S., D. Qin, M. Manning, Z. Chen, M. Marquis, K.B. Averyt, M. Tignor \& H.L. Miller (eds.). Cambridge University Press, Cambridge, United Kingdom and New York, NY, USA, 18 p.

Jylhä, K., Tuomenvirta, H. \& Ruosteenoja, K. 2004. Climate change projections for Finland during the 21st century. Boreal Environment Research 9: 127-152.

Kirchner, S.M., Hiltunen, L., Virtanen, E., Döring, T.F. \& Valkonen, J.P.T. 2009. Potato virus Y transmitting aphids in a Finnish seed potato area. In: 8th International symposium on aphids; programme and abstracts, Catania (Italy) 8-12 June 2009. p. 167.

Klein Tank, A.M.G. \& Wijngaard, J.B., et al., 2002. Daily dataset of 20th-century surface air temperature and precipitation series for the European Climate Assessment. International Journal of Climatology 22: 1441-1453.

Laurila, J., Ahola, V., Lehtinen, A., Joutsjoki, T., Hannukkala, A., Rahkonen, A. \& Pirhonen, M. 2008. Characterization of Dickeya strains isolated from potato and river water samples in Finland. European Journal of Plant Pathology 122, 2: 213-225.

Lehtinen, A., Hannukkala, A., Rantanen, T. \& Jauhiainen, L. 2007. Phenotypic and genetic variation in Finnish potato-late blight populations, 1997-2000. Plant Pathology 56: 480-491.

Lyytinen, A., Lindström, L., Mappes, J., Julkunen-Tiitto, R., Fasulati, S. \& Tiilikkala, K. 2007. Variability in host plant chemistry : behavioural responses and life-history parameters of the Colorado potato beetle (Leptinotarsa decemlineata). Chemoecology 17: 51-56.

Tiilikkala, K., Hannukkala, A., Salonen, J., Huusela-Veistola, e. Laitinen, P., Ojanen, H. \& Ooperi, S. 2010. Lisääntyvät kasvinsuojeluriskit ja niiden hallinta ilmaston muuttuessa. Maataloustieteen Päivät 2010, 1213.1.2010 (esitelmä ja sähköinen julkaisu)

Peltonen-Sainio, P., Jauhiainen, L., Hakala, K. \& Ojanen, H. 2009. Climate change and prolongation of growing season: changes in regional potential for field crop production in Finland. Agricultural and Food Science 18: 171-190. 